\title{
Gereja Partisipatif-Memasyarakat di Tengah Pandemi Covid-19
}

\author{
Yetva Softiming Letsoin a,1, Antonius Deni Firmanto ${ }^{\text {a,2 }}$, Nanik Wijiyati Aluwesia a,3 \\ ${ }^{a}$ Sekolah Tinggi Filsafat Teologi Widya Sasana Malang \\ 1 choinletsoin@gmail.com \\ 2 rm deni@yahoo.com \\ 3 nanikwa9@gmail.com
}

\section{A R T I C L E I N F O}

\section{Article History:}

Submitted: 16 April 2021

Revised: 5 September 2021

Accepted: 20 September 2021

Keywords: Covid-19 Pandemic, participatory Church, Participation, Communion, Pastoral Activity, Ritual

\section{Kata-kata Kunci: Pandemi} Covid-19, Gereja Partisipatoris, Partisipasi, Kebersamaan, Aktivitas Pastoral, Ritual

DOI:

https://doi.org/10.53396/media. $\underline{\mathrm{v} 3 \mathrm{i} 2.32}$

\section{Copyright $\odot$ 2021, Author}

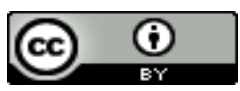

This work is licensed under a Creative Commons Attribution 4.0 International License

\section{This work is licensed under a Creative Commons Attribution 4.0 International License}

\section{ABSTRACT:}

The essay discusses the concept of the participatory and socially oriented Church in the midst of the Covid-19 pandemic. This topic departs from the reality that the Covid-19 pandemic has limited the activities of society, including ones of the ecclesial communities. The restrictions have an impact on the participation of parishioners both in their ecclesial activities and in their social involvement. In dealing with this reality, the author explores the idea of a participatory and social-involved Church in which the parishioners can take part both internally in Church life and externally in social activities. The Church must get out of the ritualistic confinement and shift the tendency of pastoral activities that are centered merely on the pastor. The method applied in this study is a qualitative method with data collection techniques using a questionnaire via google form. The author concluded that the participatory Church can be seen in its reputation as a community, communion of community, participatory Church, witnessing Church, and agent of transformation.

\section{ABSTRAK:}

Tulisan ini mendiskusikan tentang konsep Gereja Partisipatif di tengah pandemi Covid-19. Topik ini berangkat dari realitas bahwa pandemi Covid-19 telah membatasi aktivitas umat Katolik dalam kehidupan gerejani. Pembatasan tersebut berdampak pada keterlibatan umat dalam aktivitas gerejawi. Berhadapan dengan realitas ini, penulis mengeksplorasi ideal Gereja yang partisipatif dan memasyarakat. Anggota Gereja harus berpartisipasi, baik secara internal Gereja maupun secara eksternal di masyarakat. Gereja harus keluar dari kungkungan ritualistik dan menggeser tendensi kegiatan pastoral yang berpusat pada pastor. Metodologi yang digunakan dalam penelitian ini berupa metode kualitatif dengan teknik pengumpulan data menggunakan kuesioner melalui google form. Penulis menyimpulkan bahwa Gereja yang partisipatifmemasyarakat terwujud dalam gambaran Gereja sebagai persekutuan, communion of community, Gereja yang partisipatoris, Gereja yang memberi kesaksian, dan agen transformasi. 


\section{Pendahuluan}

Penelitian ini hendak menelusuri aktivitas gerejawi umat Katolik sebagai anggota Tubuh Mistik Kristus dalam situasi pandemi Covid-19. Aksentuasi penulis pertama-tama terletak pada keterlibatan umat Allah (awam Katolik) baik dalam kehidupan internal Gereja maupun dalam kehidupan masyarakat sekitar. Gereja yang terlibat dan partisipatif mengandaikan adanya partisipasi, baik secara internal maupun secara eksternal. Penulis merumuskan hal ini dalam bentuk "Gereja partisipatif-memasyarakat" di tengah pandemi Covid-19.

Realitas menunjukkan bahwa prahara Covid-19 telah membatasi kegiatan seluruh umat manusia. Kegiatan secara tatap muka atau perjumpaan langsung yang selama ini telah menjadi tradisi umat manusia harus dibatasi. Hal itu berdampak pula pada aktivitas gerejawi. Pada awal masa pandemi tidak ada umat yang dapat ke gereja atau paroki. Kemudian, hal itu diperlonggar dengan adanya batasan-batasan yang ditetapkan pemerintah. Menjelang perayaan Natal 2020, Kementerian Agama (Kemenag) menerbitkan Panduan Penyelenggaraan Kegiatan Ibadah dan Perayaan Natal di masa pandemi COVID-19. Panduan ini tertuang dalam Surat Edaran Menteri Agama nomor 23 Tahun 2020 yang ditandatangani Menteri Agama, Fachrul Razi. ${ }^{1}$

Di dalam edaran itu, umat diperbolehkan merayakan Natal, tetapi dengan mengikuti protokol kesehatan secara ketat. Pembatasan demikian tentu sangat penting demi mencegah penyebaran Covid-19. Di satu sisi, pembatasan semacam itu memperlihatkan bahwa kegiatan keagamaan termasuk pelayanan gerejawi tidak dapat terselenggara sebagaimana kondisi sebelum pandemi. Dengan begitu, pelayanan gerejawi yang selama ini dirancang dan dikonsentrasikan dari paroki harus mencari model baru agar tetap dapat berjalan. Umat tidak dapat lagi dengan gelora semangat yang tinggi dapat ke gereja, entah untuk merayakan peribadatan maupun juga mengaktualisasikan kesaksian hidup dan imannya. Lantas apakah batasan itu telah membentengi seluruh keterlibatan umat dalam tugasnya sebagai anggota Gereja?

Salah satu cetusan dasar yang digelorakan dalam Konstitusi Pastoral tentang Gereja Dewasa ini (Gaudium et Spes) adalah menghadirkan Gereja yang memasyarakat dan ambil bagian dalam kehidupan dunia. Cetusan tersebut menandaskan bahwa kegembiraan dan harapan, duka dan kecemasan orang-orang zaman sekarang, terutama kaum miskin dan siapa saja yang menderita merupakan kegembiraan dan harapan, duka dan kecemasan para murid Kristus juga. ${ }^{2} \mathrm{Hal}$ ini berarti Gereja tidak lagi bertengger hanya pada kenyamanannya, mencari kekudusannya sendiri, dan mengabaikan dunia sekitarnya yang sementara dilanda

\footnotetext{
1 "Surat Edaran Menteri Agama Nomor 23 Tahun 2020 Tentang Panduan Penyelenggaraan Kegiatan Ibadah dan Perayaan Natal di Masa Pandemi COVID-19 Kementrian Agama RI," diakses 2 September 2021, https://kemenag.go.id/archive/surat-edaran-menteri-agama-nomor-23-tahun-2020-tentang-panduan-penyelenggaraankegiatan-ibadah-dan-perayaan-natal-di-masa-pandemi-covid-19.

2 Peter Phillips, "Gaudium et Spes," Journal of Catholic Social Thought 13, no. 2 (2016): 245-59, https://doi.org/10.5840/jcathsoc20161327.
} 
Covid-19. Gereja yang dicetuskan adalah persekutuan dari umat-umat beriman yang terlibat, baik dalam kehidupan internal maupun kehidupan eksternal Gereja. Dengan demikian, kata kunci yang tampak di sini adalah keterlibatan.

Apabila menyelisik rekam jejak perjalanan Gereja terutama pada zaman modern ini, dapat ditemukan bahwa masih ada umat yang menjadi pengamat pasif dan berdiri di garis pinggir kehidupan menggereja. Kehidupan Gereja dipahami dengan terbatas pada ritual dan perayaan liturgis melulu. Terlebih, berpikir tentang Gereja secara langsung mengidentikkannya dengan pastor atau imam di paroki, termasuk juga kaum biarawan/wati. Atas dasar pemahaman semacam itu, keterlibatan umat dalam kehidupan menggereja terbatas hanya sampai pada pengecap rasa, bukan penikmat yang ikut menikmati pahitmanisnya, baik-buruknya, suka-dukanya, dan ketar-ketirnya Gereja. Afirmasi demikian bukan bermaksud mengabaikan peran sekian banyak umat yang selama ini telah masuk ke inti hidup menggereja, tetapi terlebih hendak mengintervensi sikap pasif dan tidak peduli umat maupun klerus dalam gagasan Gereja yang partisipatif dan memasyarakat. Dalam situasi pandemi Covid-19, situasi demikian dapat saja semakin diperparah oleh adanya batasan untuk beraktivitas di Gereja.

Melalui penelitian ini, pertama-tama penulis bermaksud mengetahui sejauh mana implementasi dan penghayatan Gereja yang "Partisipatif-Memasyarakat" dalam kehidupan umat Katolik di Paroki Kesatrian Keuskupan Malang, secara khusus selama pandemi Covid19. Tujuan jauhnya adalah meningkatkan kesadaran umat Paroki Ratu Rosari Malang akan perannya sebagai Gereja yang mengumat dan memasyarakat, dan tidak tergeser ke pinggir oleh Gereja devosional, Gereja ritual, dan Gereja ziarah-ziarah. Sebelum sampai ke tujuan itu, perlu diketahui sejauh mana Gereja Paroki Ratu Rosari, terutama umatnya telah mengambil bagian dalam kehidupan internal maupun eksternal Gereja selama Covid-19.

\section{Metode Penelitian}

Untuk sampai kepada temuan dari penelusuran ini, beberapa rumusan masalah diutarakan penulis melalui Research Question yang dibuat dalam bentuk kuesioner dengan menggunakan google form untuk selanjutnya diedarkan ke 113 orang responden atau umat Katolik Paroki Kesatrian yang penulis tentukan sebagai objek penelitian. Research Question diajukan penulis dalam bentuk afirmasi maupun pertanyaan, dan memberikan pilihan kepada objek penelitian yang akan diterangkan lebih jelas pada bagian deskripsi hasil penelitian. Ada pun Research Question itu adalah antara lain sebagai berikut.

- Sebelum pandemi Covid-19, saya aktif dalam kehidupan menggereja di paroki.

- Selama masa pandemi Covid-19, saya aktif dalam kehidupan menggereja di paroki.

- Kegiatan-kegiatan kegerejaan yang saya ikuti selama pandemi Covid-19 adalah..

- Saya menghadiri kegiatan gerejani di gereja paroki. 
- Selama pandemi Covid-19, saya mendapat tugas pelayanan pada saat perayaan ekaristi maupun kegiatan lainnya di Paroki .

- Apakah selama pandemi Covid-19 kegiatan kegerejaan hanya dilakukan oleh para imam saja?

- Apakah selama pandemi Covid-19 kegiatan kegerejaan hanya dilakukan atau didominasi oleh beberapa orang umat saja?

- Selama masa pandemi, saya terlibat dalam kegiatan di lingkungan masyarakat saya tinggal

- Kegiatan kemasyarakatan yang saya ikuti selama masa pandemi Covid-19 adalah...

- Saya memberikan bantuan secara materi kepada masyarakat/warga yang terdampak secara ekonomi.

Ke sepuluh Research Question di atas sejatinya memuat dan mengarah kepada tiga rumusan masalah yang diutarakan penulis dalam tulisan ini. Pertama, apakah yang dilakukan umat Katolik berkaitan dengan kegiatan internal Gereja di masa pandemi? Kedua, apakah yang dilakukan umat Katolik berkaitan dengan kegiatan eksternal Gereja selama pandemi? Ketiga, apakah aktivitas gerejawi selama pandemi ini berciri pastor-sentris atau hanya didominasi oleh beberapa orang umat saja?

Dari situ, penulis kemudian menggunakan metode penggalian dan analisis data yang telah diperoleh dari hasil quisioner penelitian, dan akan ditampilkan pada bagian ketiga dari tulisan ini. Data hasil penelitian kemudian direfleksikan secara mendalam dengan menggunakan metode analisa teks dan tinjauan literatur. Data-data yang diperoleh penulis nantinya memberikan jawaban atas diskursus partisipasi umat Katolik dalam kehidupan Gereja dan Masyarakat di tengah pandemi Covid-19. Penulis mencoba memberikan penjelasan dan penafsiran, serta menawarkan arah pemahaman baru mengenai Gereja yang partisipatif-memasyarakat di tengah prahara pandemi. Akan tetapi, sebelum sampai kepada tahap itu landasan teori atas Gereja Partisipatif-Memasyarakat perlu ditelusuri lebih mendalam.

\section{Hasil dan Pembahasan}

\section{Berbagai Perspektif atas Gereja "Partisipatif-Memasyarakat"}

Gagasan "Gereja Partisipatif Memasyarakat" berdasar pada ide yang dicetuskan oleh John Mansfor Prior dalam buku Allah Menggugat-Allah Menyembuhkan. ${ }^{3}$ Menurut Prior, pasca Konsili Vatikan II Gereja sesungguhnya belum bebas dari jeratan perspektif Gereja yang kaku-hirarkis. Cetusan demikian ditandaskan atas pengamatan terhadap realitas yang memperlihatkan the full power of hierarchy dalam hampir seluruh tatanan hidup

\footnotetext{
${ }^{3}$ John Mansford Prior, Allah Mengugat Allah Menyembuhkan, ed. Paul Budi Kleden, dkk. (Maumere: Ledalero, 2012).
} 
menggereja. Teologi Gereja yang Memasyarakat (GS 1) tapak demi tapak dihimpit oleh tata kelola Gereja yang menegakkan kembali pola monarki-klerikal, hierarki tanpa konsultasi yang berarti, tanpa akuntabilitas. Sebagian besar umat awam pasrah, tunduk dan menerima kemunduran ini. ${ }^{4}$

Asumsi di atas akan semakin diperparah oleh kenyataan bahwa pandemi Covid-19 secara eksplisit membatasi karya, keikutsertaan, dan pelayanan umat awam Katolik dalam kehidupan menggereja. Batasan itu dapat diketahui secara gamblang dari adanya peraturan mengenai kehadiran umat di Gereja. Gereja sejatinya menjadi sentrum dari segala aktivitas umat. Dari sanalah mengalir aktivitas atau implementasi iman umat secara internal maupun eksternal. Tetapi pandemi Covid-19 membatasi kehadiran umat di gereja. Dalam konteks ini, keterlibatan atau partisipasi umat mesti ditelusuri kembali.

Keterlibatan umat dalam konteks gagasan Gereja Partisipatif-Memasyarakat menunjuk kepada keterlibatan anggota dalam aktivitas internal maupun eksternal Gereja. Jadi, diperlukan semacam intervensi atas keterlibatan dalam dua bingkai itu dengan maksud menggeser perhatian atau fokus utama Gereja dari kurungan-kurungan ritualistik devosional ke masalah-masalah kemasyarakatan, dan menghadirkan Gereja ke tengah arus utama bangsa yang sibuk membangun negara yang bebas dan sejahtera. Pada kisaran tahun 19621965 Gereja Katolik Indonesia telah berusaha dengan sadar berikhtiar beralih dari Gereja Katolik di Indonesia menjadi Gereja Katolik Indonesia. Beriringan dengan kesadaran itu, muncul pula gagasan "awamisasi” atau "indonesianisasi” Gereja yang dimaksudkan untuk mengungkapkan dan mendorong pembaruan Gereja Katolik Indonesia. ${ }^{5}$

Cetusan Gereja yang partisipatif mesti kembali dilihat dari perspektif salah satu dokumen konstitusi Gereja, yakni Lumen Gentium tentang misteri Gereja. Pertama-tama, Gereja dipandang sebagai sakramen keselamatan yaitu "tanda dan sarana persatuan yang mesra dengan Allah dan keseluruhan umat manusia" (LG 1). Di sini gagasan pokok yang ditandaskan bermuara pada konsep tentang Gereja sebagai sarana keselamatan. Artinya, Gereja sesungguhnya hadir sebagai sakramen keselamatan yang menjembatani orang-orang beriman dan umat manusia pada umumnya kepada keselamatan.

Lumen Gentium kemudian secara runtut menegaskan gagasan itu. Keselamatan umat manusia itu merupakan rencana kehendak Bapa (bdk. LG 2). Rencana itu telah dimulai dalam Perjanjian Lama dan kemudian memuncak pada Perjanjian Baru, yakni dalam perutusan Yesus Kristus (bdk. LG 3). Kemudian, ketika sudah selesailah karya, yang oleh Bapa dipercayakan kepada Putera untuk dilaksanakan di dunia (lih. Yoh. 17:4), diutuslah Roh Kudus pada hari Pentakosta, untuk tiada hentinya menguduskan Gereja (bdk. LG 4). Setelah mendapat kekuatan dan bimbingan dari Roh Kudus, Gereja diutus untuk mewartakan Kerajaan Allah di tengah-tengah bangsa manusia (bdk. LG 5), di mana Gereja itu sendiri memiliki beragam gambaran (bdk. LG 6), yang mana seluruh anggotanya

\footnotetext{
${ }^{4}$ Prior, 109.

5 Prior, 109.
} 
disatukan dalam Tubuh Kristus (bdk. LG 7) dengan tujuan menyalurkan buah-buah keselamatan kepada setiap individu manusia.

Jika dikaitkan dengan konteks penelusuran artikel ini, pandangan Lumen Gentium di atas memperjelas arti Gereja yang partisipatif, yang tujuannya adalah Gereja mengambil bagian dalam perutusan Kristus, yaitu menghadirkan Kerajaan Allah di dunia. Kehadiran Kerajaan Allah pun bermuara kepada tujuan dasar, yakni keselamatan umat manusia. Pernyataan ini mesti dilandasi oleh kesadaran bahwa Gereja partisipatoris melibatkan seluruh komponen Gereja. Kehidupan Gereja tidak hanya didominasi oleh hierarki, tetapi juga mengandaikan keterlibatan aktif kaum awam. Awam tidak dilihat lagi sebagai objek pelayanan hierarki, melainkan subjek aktif pelayanan. Awam juga memiliki peran dan tanggung jawab dalam Gereja. Peran khusus mereka adalah mengubah dunia dengan terang Injil. Tugas mereka bukan mandat dari hierarki, tetapi karena iman dan pembaptisan. ${ }^{6}$

Bentuk konkret dari Gereja yang menghadirkan sekaligus menjadi tanda keselamatan tampak bukan hanya dalam konteks internal hidup gerejani, tetapi lebih jauh dalam masalahmasalah sosial yang menggerogoti realitas kehidupan manusia pada umumnya. Itu berarti diperlukan gagasan atau konsep Gereja yang terlibat. Gereja yang terlibat dalam kehidupan sosial kemasyarakatan dapat ditandaskan sebagai Gereja yang memasyarakat. Cetusan ini dapat ditelusuri dari sudut pandang Gaudium et Spes art.1.

GS 1 mengungkapkan bahwa kegembiraan dan harapan, duka dan kecemasan, orangorang pada zaman sekarang, terutama kaum miskin dan siapa saja yang menderita merupakan kegembiraan dan harapan, duka dan kecemasan para murid Kristus juga. Di sini termaktub peran Gereja dalam kehidupan sosial kemasyarakatan. Situasi pandemi Covid-19 pada kenyataannya telah memperparah kemiskinan umat manusia. Banyak orang menganggur karena kurangnya lapangan kerja. Tentu Gereja sebagai sakramen keselamatan tidak dapat menutup mata atas realitas kemiskinan dan prahara penderitaan manusia semacam itu. Panggilan Gereja yang partisipatif dan memasyarakat mendapat tempatnya dalam situasi ini.

Di samping, gagasan-gagasan di atas, penulis menganggap perlu untuk melihat Gereja Partisipatif-memasyarakat dalam konteks Asia. Pertanyaan mendasar adalah bagaimana caranya menjadi Gereja Asia supaya Gereja tidak dianggap asing atau berbau barat. Menyangkut kegelisahan ini, unsur-unsur New way of being church in Asia yang disarikan oleh Alis Windu Prasetyo dan Dionisius Bismoko Mahamboro memiliki fondasi yang penting. ${ }^{7}$ Cetusan mereka tentang Gereja di Asia dapat ditampilkan seperti berikut ini:

- Communion of community. Gereja yang terdiri dari berbagai macam orang, baik religius maupun non-religius dipanggil bersama-sama oleh Sabda Allah untuk membangun komunitas. Semua anggota komunitas itu berdoa dan berbagi bersama

\footnotetext{
${ }^{6}$ Novry Dien, “Gereja Persekutuan Umat Allah,” Media (Jurnal Filsafat dan Teologi) 1, no. 1 (2020): 49-64. ${ }^{7}$ Alis Windu Prasetyo dan Dionius Bismoko Mahamboro, "BERKUBANG DALAM LUMPUR, BEKERJA BERSAMA ORANG MISKIN, Wajah Keterlibatan Sosial Gereja Ganjuran,” Jurnal Teologi (Journal of Theology) 2, no. 1 (2014): 83-91.
} 
akan Kabar Gembira Yesus, hidup bersama dalam keseharian, mendukung satu sama lain dan bekerja bersama dalam kesatuan hati dan budi.

- Gereja yang partisipatoris. Ini adalah rahmat Roh Kudus yang diberikan kepada semua orang beriman di dalam Gereja. Roh Kuduslah yang mengenali dan menggerakkan Gereja sehingga dapat menjalankan tugas perutusannya yaitu mewartakan Sabda.

- Gereja yang memberi kesaksian. Kebangkitan Kristus yang diwartakan Gereja diwujudkan dalam dialog kehidupan dengan semua orang (yang berlainan kepercayaan) menuju pembebasan yang integral. Di Keuskupan Agung Semarang hal ini dimunculkan dalam istilah "Gereja yang memasyarakat" sejak Ardas periode pertama.

- Agen transformasi. Dengan iman dan harapan yang berdimensi eskatologis, sudah menjadi penghayatan umat beriman untuk memahami bahwa kehidupan bukan berhenti di dunia ini. Perjuangan dalam perubahan sosial masyarakat didorong oleh penghayatan iman yang berdimensi eskatologis. Dunia yang lebih baik selalu harus diwujudkan.

Perspektif-perspektif di atas dibuat sebagai titik tolak dalam penelusuran demi menekankan kembali kekuatan Gereja sebagai sebuah persekutuan yang partisipatif. Peranperan umat ditingkatkan dalam kehidupan internal Gereja, dan bukan hanya tunduk pada perintah pastor paroki. Umat mesti mampu berperan dalam kehidupan Gereja untuk mampu menganimasi dirinya, bukan hanya melulu atau terus menerus dianimasi oleh pastor paroki. Dalam kehidupan eksternal, Gereja terlibat aktif bersuara, bertindak, dan berperan dalam urusan kemasyarakatan.

Di balik pandangan ini, ada kegelisahan bahwa apabila dipertahankan Gereja yang identik dengan para imam atau Gereja yang institusional, maka lama kelamaan Gereja akan ditinggalkan. Umat akan berpaling kepada kehidupan yang memenuhi harapannya, yang tidak ditemukan dalam Gereja. Nanti akan diperparah oleh meledaknya sekularisme, hedonisme, dan pengabaian moralitas. Lalu, Gereja dianggap asing, atau bahkan bukan bagian dari masyarakat. Dengan begitu, Pandemi Covid-19 nantinya mereduksi wajah solidaritas Gereja.

Hal ini kemudian mendorong penulis untuk melakukan elaborasi atas realitas kehidupan gerejawi umat Paroki Kesatrian selama pandemi Covid-19. Sebelum menuju kepada hasil elaborasi itu, penulis menampilkan hasil penelitian sebagai berikut.

Kegiatan Internal Gerejawi Umat Paroki Ratu Rosari Kesatrian Malang selama Masa Pandemi Covid-19

Melalui kuesioner yang dibagikan penulis kepada responden, penulis pertama-tama menyelidiki komparasi antara kegiatan gerejawi yang diikuti sebelum pandemi dan selama pandemi. 
Sebelum pandemi Covid-19, saya aktif dalam kehidupan menggereja di Paroki. 113 jawaban
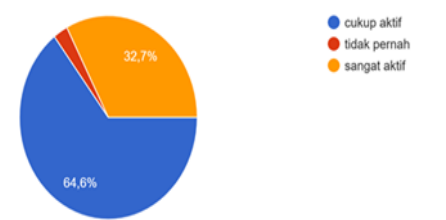

Selama masa pandemi Covid-19, saya aktif dalam kehidupan menggereja di Paroki. 112 jawaban

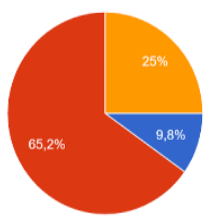

Berdasarkan data yang diperoleh, komparasi yang ditemukan adalah sebagai berikut:

- Sebelum pandemi $32 \%$ responden sangat aktif dalam kegiatan gerejawi, sementara selama masa pandemi hanya $9,8 \%$ responden.

- Sebelum pandemi, $64 \%$ responden cukup aktif dalam kehidupan gerejani, sedangkan selama pandemi meningkat menjadi $65,2 \%$ responden.

- Sebelum pandemi $2,7 \%$ responden tidak pernah aktif dalam kehidupan gerejani, sedangkan selama pandemi meningkat sangat pesat menjadi $25 \%$ responden. Dari sini dapat diketahui bahwa pandemi Covid-19 telah menambah angka ketidak-aktifan umat Katolik dalam aktivitas gerejawi. Angka peningkatannya sangat besar yaitu, 22,3\%.

Pada bagian selanjutnya, penulis mengamati kegiatan-kegiatan yang dilakukan oleh umat Katolik Paroki Kesatrian selama masa pandemi. Data yang diperoleh adalah sebagai berikut.

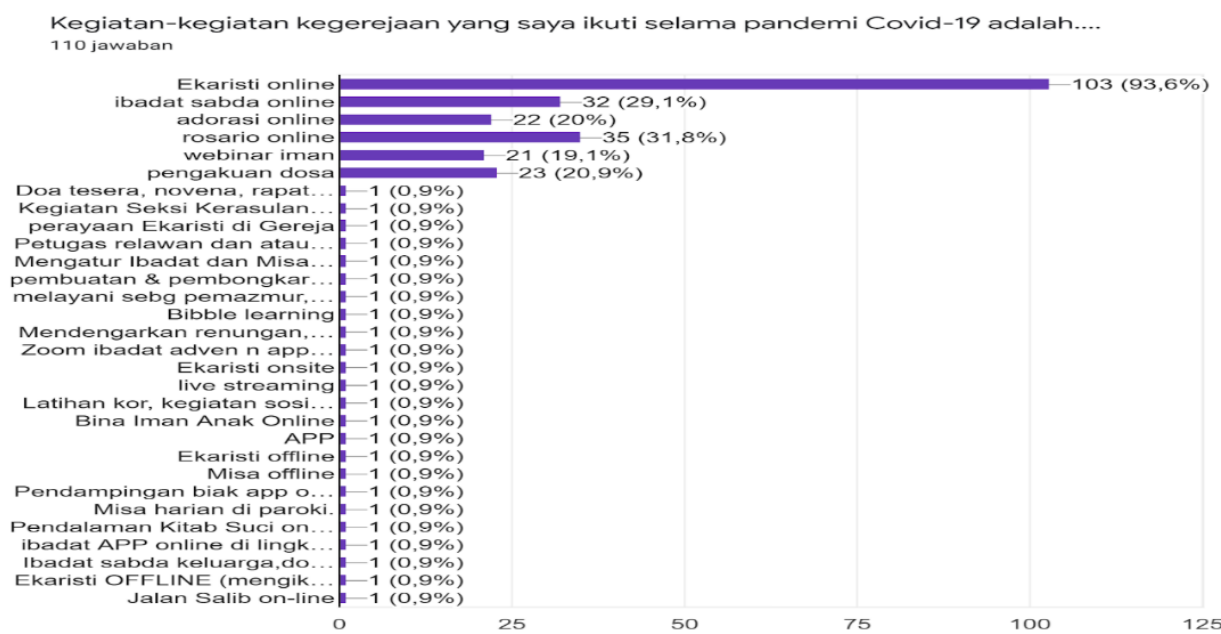

Berdasarkan data-data tadi, kegiatan gerejawi yang diikuti oleh umat Katolik Paroki Ksatrian selama pandemi adalah Ekaristi Online (93, 6 \% responden), ibadat sabda online 
$(29,1 \%)$, adorasi Online $(20,0 \%)$, rosario online (31,8 \%), webinar iman $(19,1 \%$,), pengakuan dosa $(20,9 \%)$. Lalu dikuti juga oleh masing-masing kegiatan lainnya, seperti jalan salib online, ibadat Adven online, pendalaman Kitab Suci, latihan kor, mendengarkan renungan di youtube, dan bina iman anak. Tiap-tiap kegiatan tersebut diikuti oleh $0,9 \%$ responden.

Hal lain yang perlu diselidiki adalah apakah umat Katolik Kesatrian menghadiri secara fisik kegiatan-kegiatan di gereja. Penulis menampilkan datanya sebagai berikut.

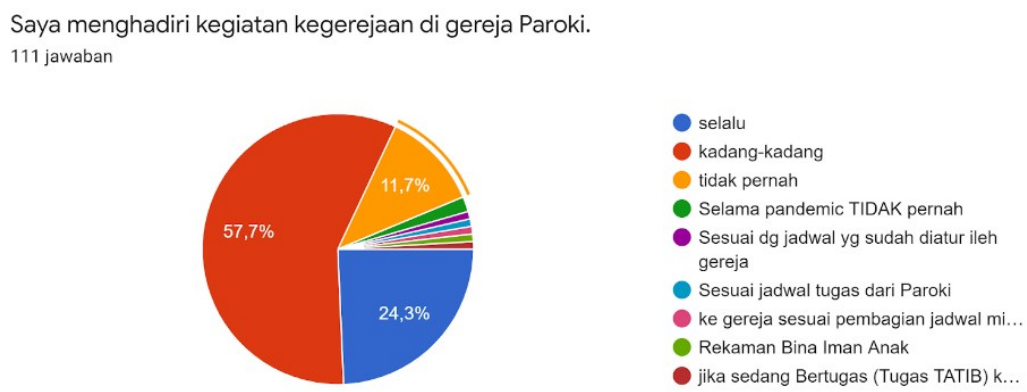

Dari data yang ditampilkan di atas, 11,7 persen umat Katolik Paroki Kesatrian tidak pernah ke gereja paroki selama pandemi. 57,7 \% responden mengungkapkan bahwa mereka kadang hadir ke gereja paroki, sedangkan $24 \%$ responden selalu pergi ke Paroki. Dengan demikian kehadiran, umat ke gereja selama pandemi cukup aktif, tetapi harus mengikuti protokol kesehatan dan aturan yang dibuat paroki yaitu menghadiri kegiatan per wilayah.

Untuk mengetahui apakah umat terlibat dalam kegiatan pelayanan di paroki, penulis memperoleh data sebagai berikut.

Selama pandemi Covid-19, Saya mendapat tugas pelayanan pada saat perayaan Ekaristi maupun kegiatan lainnya di Paroki .

110 jawaban
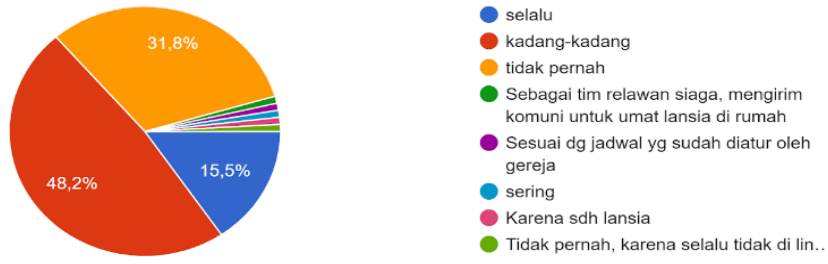

Berdasarkan data di atas, dapat dideskripsikan bahwa $31 \%$ umat Kesatrian tidak pernah mendapat tugas pelayanan di paroki. $48 \%$ mengungkapkan kadang-kadang memperoleh tugas pelayanan, $15 \%$ sering. Dari data demikian, penulis melihat bahwa kehadiran umat dalam kegiatan pelayanan di paroki Kesatrian tidak terlalu tinggi. 


\section{Kegiatan Eksternal Gerejawi Umat Paroki Kesatrian selama Pandemi}

Berikut ini adalah data yang berkaitan dengan kegiatan eksternal yang dilakukan umat Kesatrian selama masa pandemi. Namun sebelum itu, penulis menyelidiki apakah selama masa pandemi Umat Katolik Paroki Kesatrian terlibat dalam kegiatan di lingkungan masyarakat mereka tinggal. Data yang diperoleh ditampilkan sebagai berikut.

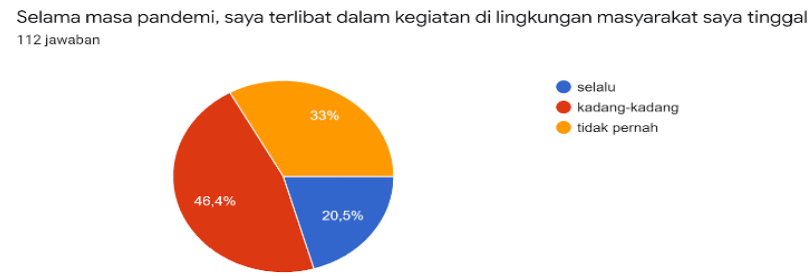

Dari data di atas, 20,5\% responden mengungkapkan bahwa mereka selalu terlibat dalam kegiatan masyarakat di tempat mereka tinggal; $46 \%$ mengungkapkan bahwa mereka kadang-kadang ikut, sedangkan $33 \%$ mengungkapkan mereka tidak pernah ikut terlibat dalam kegiatan masyarakat. Dari data itu, penulis menyimpulkan bahwa keterlibatan umat Paroki Ksatrian dalam kegiatan kemasyarakatan tidak terlalu tinggi.

Selanjutnya, penulis menyelidiki jenis kegiatan yang dilakukan umat Kesatrian sebagai bentuk keterlibatan mereka dalam kehidupan masyarakat. Penulis memperoleh data sebagai berikut.

Kegiatan kemasyarkatan yang saya ikuti selama masa pandemi Covid-19 adalah.. 90 jawaban

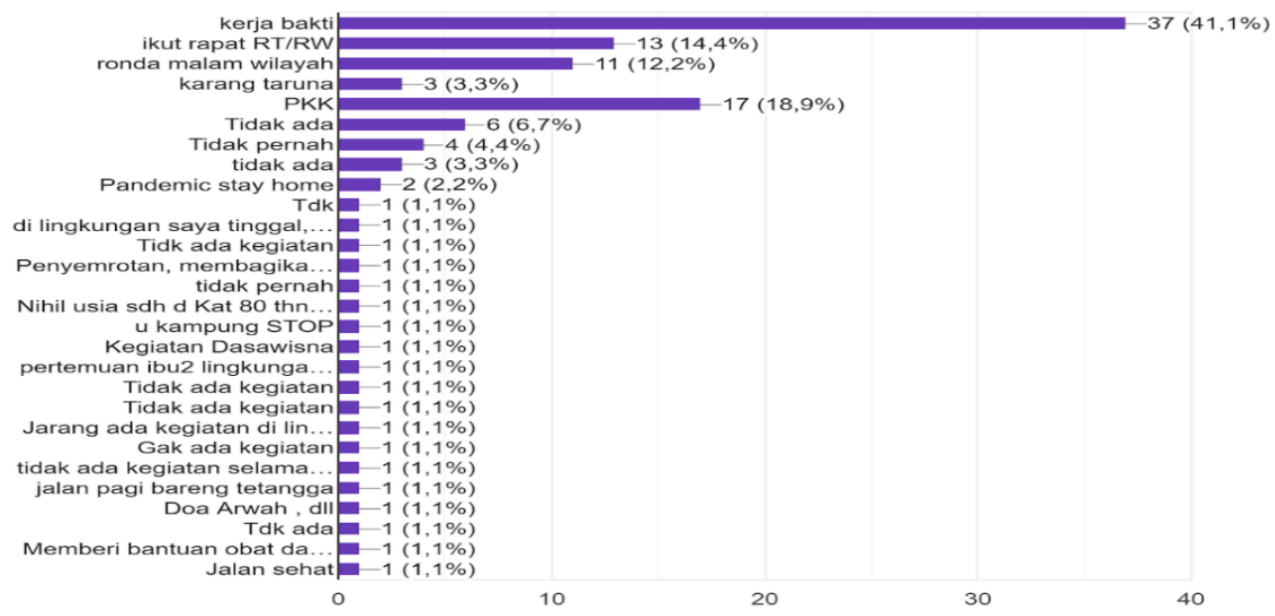

Dari data tersebut, jenis kegiatan yang diikuti antara lain kerja bakti (37\%), ikut rapat $(14,4 \%)$, ronda malam wilayah $(12,2 \%)$, karang taruna (3\%), kegiatan ibu-ibu PKK 
$(18,9 \%)$. Kegiatan lain yang diikuti adalah dasawisma dan jalan sehat. Tiap kegiatan tersebut diikuti oleh seorang responden. Banyaknya jawaban dalam kurva disebabkan oleh adanya pilihan jawaban yang penulis berikan kepada responden. Namun, tampak bahwa meskipun situasi pandemi, masih ada umat Katolik paroki Kesatrian yang terlibat dalam kegiatan kemasyarakatan.

Selain itu penulis juga melihat sikap solider umat Kesatrian dengan mencari tahu apakah mereka juga ikut memberikan donasi kepada sesama yang terdampak secara materi. Berikut ini adalah data yang diperoleh penulis.

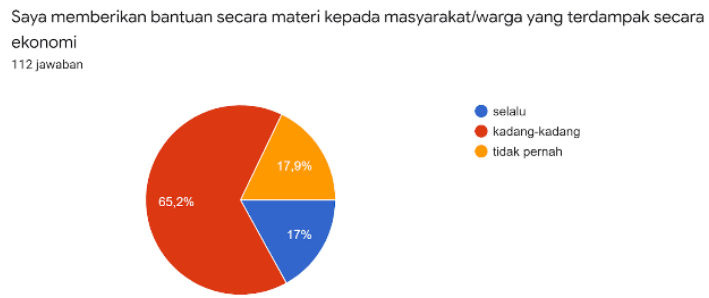

Dari situ dapat diketahui bahwa $17 \%$ di antara responden tidak pernah memberikan bantuan material kepada warga yang terdampak pandemi; $65,2 \%$ kadang-kadang memberikan, dan 17, $9 \%$ selalu memberikan bantuan. Tampaknya, solidaritas untuk berbagi dari umat Katolik Paroki Ratu Rosari Kesatrian Malang cukup tinggi.

\section{Pelaku Utama Kegiatan Gerejawi selama Pandemi Covid-19 di Paroki Ratu Rosari Kesatrian Malang}

Penulis kemudian melalui rumusan masalah yang ketiga mencoba menyelidiki para pelaku utama kegiatan gerejawi selama pandemi. Untuk mencapai tujuan itu, penulis melalui kuesioner mencari tahu dominasi pastor paroki atau umat tertentu saja. Data yang diperoleh adalah sebagai berikut.

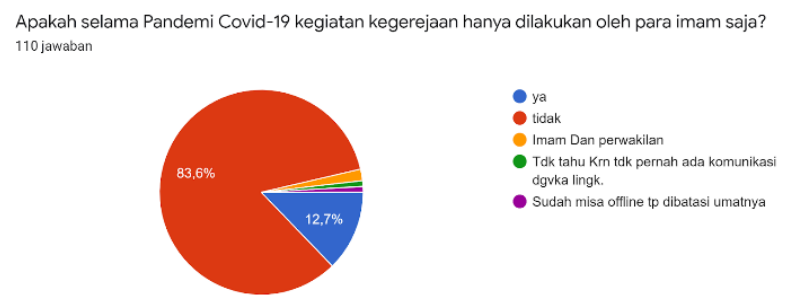

$83 \%$ responden tidak menyetujui bahwa kegiatan Gerejawi hanya dilakukan oleh imam saja; 12, 7 Persen menyetujui, dan 0,9\% responden tidak tahu. Dari situ penulis menyimpulkan bahwa kegiatan kegerejaan selama pandemi di paroki Ratu Rosari Kesatrian 
Malang tidak berciri pastor sentris. Selanjutnya, penulis juga hendak menelusuri apakah kegiatan kegerejaan hanya didominasi oleh beberapa orang umat saja. Berikut ini adalah data yang diperoleh.

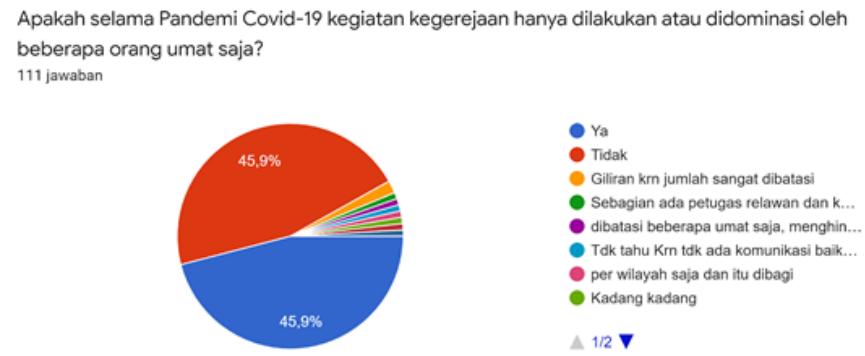

Terdapat $45 \%$ responden yang tidak menyetujui bahwa kegiatan gerejawi hanya didominasi oleh beberapa umat saja. 45, $9 \%$ menyetujui dan $6,7 \%$ responden berpendapat tidak tahu. Dapat disimpulkan di sini bahwa selama pandemi ini kegiatan kegerejaan sejatinya lebih didominasi oleh beberapa umat. Kenyataan demikian bisa saja terjadi mengingat adanya larangan atau peraturan pemerintah untuk membatasi kegiatan keagamaan.

Gereja-Partisipatif-Memasyarakat di Tengah Pandemi Covid-19: Realitas Aktivitas Gerejawi Umat Katolik Paroki Ratu Rosari Kesatrian Malang

Berdasarkan penelitian sebelumnya, 113 responden dari umat Katolik Paroki Ratu Rosari Kesatrian Malang dijadikan acuan penulis untuk memberikan gambaran terhadap ciri khas Gereja "Partisipatif-Masyarakat" yang menjadi orientasi dalam tulisan ini. Data menunjukkan bahwa terjadi penurunan responden yang sangat aktif dalam kehidupan menggereja di Paroki Ratu Rosari antara sebelum pandemi dan selama pandemi. Dari situ dapat disimpulkan bahwa responden yang sangat aktif dalam kehidupan menggereja selama ini akhirnya menjadi kurang aktif dalam masa pandemi Covid-19. Hal ini menjadi perhatian utama untuk analisa dan penelusuran penulis dalam tulisan ini.

Keterlibatan aktif anggota Gereja dalam kegiatan internal Gereja pada hakikatnya merupakan bentuk penghayatan iman. Hanya saja akibat pandemi, perayaan iman dibatasi. Mayoritas umat mengadakan Ekaristi secara online. Hal ini dapat berdampak pada mereduksinya nilai persekutuan dalam Gereja. Bagaimanapun, setiap anggota Gereja dipanggil dan dibaptis untuk hidup dalam suatu comunio atau persekutuan. Hubungan personal-komunal dari orang terbaptis menggambarkan karakteristik Gereja sebagai suatu Umat Allah yang baru. Umat Allah yang baru ini dibentuk oleh Roh Kudus dan disusun dalam comunio di antara orang-orang terbaptis. Secara hierarkis mereka disatukan dengan 
perbedaan fungsi-kedudukan dalam aneka karisma dan pelayanan, dalam iman yang sama, dalam sakramen-sakramen dan pemerintahan gerejawi. ${ }^{8}$

Intinya, Gereja dipanggil untuk membentuk suatu persekutuan. Persekutuan mengandaikan suatu keterlibatan. Persekutuan tanpa keterlibatan akan menimbulkan emblem pengasingan Gereja. Jadi, gagasan Gereja sebagai persekutuan mendesak tiap-tiap anggota Gereja untuk hadir dalam aktivitas gerejawi. Lebih jauh, kehadiran itu termaktub dalam perjumpaan. Subyek yang hadir dalam suatu persekutuan berbeda dari subyek yang $a d a$ dalam persekutuan tersebut. Subyek yang hadir memperlihatkan di dalam dirinya suatu aksi nyata dalam persekutuan itu. Aksi nyata yang dimaksudkan di sini tidak lain dari perjumpaan itu sendiri. Jadi, setiap individu hadir dalam perjumpaan, dialog, kerja sama, ataupun tukar gagasan atau ide dengan individu yang lain. Dalam hal itulah keterlibatan dihadirkan sebagai realitas hidup anggota Gereja.

Di samping itu, mayoritas keterlibatan umat Paroki Kesatrian dalam aktivitas internal Gereja terletak pada perayaan Ekaristi. Sakramen Ekaristi sejatinya membentuk dan memupuk kesatuan umat Allah dan umat yang sudah dipersatukan dengan memperdamaikan berbagai suku dan golongan dalam dirinya, menjadi tanda dan sarana demi persatuan dan perdamaian dalam masyarakat luas. ${ }^{9}$

Persekutuan sebagaimana telah diungkapkan pada bagian sebelumnya mendapat legitimasinya pada makna persekutuan dalam perayaan Ekaristi. Namun, ketika pandemi umat dibatasi dalam merayakan Ekaristi. Hal itu berdampak pula pada lenyapnya perjumpaan fisik antar umat. Persekutuan telah dimaknai di sini sebagai suatu keterlibatan yang nyata dalam perjumpaan langsung, di mana perjumpaan langsung itu diperlihatkan dalam dialog, kerja sama, dan tukar gagasan atau ide dengan sesama umat. Hal-hal ini telah tereduksi oleh situasi pandemi karena tidak adanya perjumpaan fisik tiap-tiap individu umat Katolik. Perjumpaan fisik sebenarnya semakin memperteguh makna kesatuan dan comunio dalam perayaan Ekaristi itu sendiri.

Gagasan persekutuan ini sebenarnya telah mengafirmasi unsur Gereja sebagai community of communities. Gereja yang terdiri dari berbagai macam orang, baik religius maupun non-religius dipanggil bersama-sama oleh Sabda Allah untuk membangun komunitas seperti yang dicetuskan oleh konferensi para Uskup Asia. ${ }^{10}$ Semua anggota komunitas itu berdoa dan berbagi bersama akan Kabar Gembira Yesus, hidup bersama dalam keseharian, mendukung satu sama lain dan bekerja bersama dalam kesatuan hati dan budi. Makna persekutuan Gereja sesungguhnya ditemukan di sini. Tetapi pertanyaan selanjutnya apa makna persekutuan Gereja di tengah Pandemi Covid-19? Menurut penulis,

\footnotetext{
8 Higianes Indro Pandego, "GEREJA UMAT ALLAH SEBAGAI KOMUNIO PARTISIPATIF Refleksi YuridisPastoral atas KHK 1983, Kann.204-207," LOGOS 17, no. 2 (16 Juli 2020): 106-27.

${ }^{9}$ George Kirchberger, Allah Menggugat (Maumere: Ledalero, 2007).

${ }^{10}$ Jonathan Yun-Ka Tan, “A New Way of Being Church in Asia: The Federation of Asian Bishops' Conferences (FABC) at the Service of Life in Pluralistic Asia," Missiology: An International Review 33, no. 1 (Januari 2005): 72-94, https://doi.org/10.1177/009182960503300107.
} 
makna persekutuan umat yang sejati tidak lagi ditemukan dalam situasi pandemi. Makna persekutuan lebih kepada persekutuan batin dari orang-orang yang dipanggil. Umat hanya bersekutu dalam Gereja yang terjaring secara virtual, tidak ada perjumpaan fisik, hanya perjumpaan virtual saja. Maka hemat saya, makna persekutuan Gereja lebih kepada persekutuan batiniah.

Persekutuan Gereja mengandaikan suatu keterlibatan, maka muncullah cetusan Gereja yang partisipatoris. Ini adalah rahmat Roh Kudus yang diberikan kepada semua orang beriman di dalam Gereja. Roh Kuduslah yang mengenali dan menggerakkan Gereja, sehingga ia dapat menjalankan tugas perutusan mewartakan Sabda. ${ }^{11}$ Kita dapat mengatakan bahwa keterlibatan mengandung di dalamnya suatu aktivitas untuk mewartakan sabda Allah. Ketika aktivitas gerejawi umat selama pandemi lebih berorientasi pada mengikuti perayaan Ekaristi secara online, maka nyaris tidak ditemukan di dalamnya suatu aktivitas mewartakan sabda. Mengikuti perayaan Ekaristi adalah kegiatan yang paling fundamental dari hidup sebagai orang Kristen. Jika tidak diikuti oleh tindakan yang nyata sebagai buahnya, aktivitas ini tetap berada pada tataran pasif.

Oleh karena itu, Gereja yang terlibat termasuk pula dalam gagasan Gereja yang memberi kesaksian. Kebangkitan Kristus yang diwartakan oleh Gereja diwujudkan dalam dialog kehidupan dengan semua orang (yang berlainan kepercayaan) menuju pembebasan yang integral. Keuskupan Agung Semarang sejak Ardas periode pertama menggagas istilah "Gereja yang memasyarakat". ${ }^{12}$ Dalam gagasan ini, Gereja yang memasyarakat mendapat legitimasinya. Dalam penelitian sebelumnya, ditemukan bahwa $33 \%$ responden tidak pernah mengikuti aktivitas kemasyarakatan selama pandemi Covid-19. Dengan demikian, tidak ada perjumpaan dengan realitas pluralitas masyarakat. Tidak ada dialog dengan orang yang berlatar belakang agama berbeda, dan seterusnya. Ini menjadi salah satu kegelisahan sendiri sebagai dampak dari Covid-19.

Apabila kenyataan ini disendengkan dengan menyelisik kembali makna Wahyu, maka keterlibatan Gereja memiliki makna baru. Wahyu adalah suatu komunikasi diri Allah. Allah secara luar biasa mengomunikasikan dan menawarkan diri-Nya kepada manusia dalam relasi. Tujuan Allah adalah untuk menawarkan relasi dan persahabatan. ${ }^{13}$ Gagasan ini mengandung implikasi logis bagi umat Kristiani. Mereka dipanggil untuk membangun relasi dan persahabatan dengan siapa pun secara inklusif. Relasi dan persahabatan yang dibangun dengan orang dari berbagai latar belakang merupakan suatu bentuk keterlibatan sebagai Gereja yang memasyarakat. Sebab, tujuan dari keterlibatan Gereja dalam masyarakat adalah untuk membangun persahabatan dan memperkokoh relasi persaudaraan dan kemanusiaan.

Di samping itu, Gereja yang terlibat adalah agen transformasi. Dengan iman dan harapan umat beriman memahami dan menghayati bahwa kehidupan bukan berhenti di

\footnotetext{
${ }^{11}$ Prasetyo dan Mahamboro, "BERKUBANG DALAM LUMPUR," 83-91.

${ }^{12}$ Prasetyo dan Mahamboro, 83-91.

${ }^{13}$ Stephen Bevans, Teologi dalam Perspektif Global (Maumere: Ledalero, 2010).
} 
dunia ini. Perjuangan dalam perubahan sosial masyarakat didorong oleh penghayatan iman yang berdimensi eskatologis. Dunia yang lebih baik selalu harus diwujudkan. ${ }^{14}$ Gagasan ini mendorong pentingnya Gereja untuk keluar dari kungkungan ritualistik. Agama pada kenyataannya tidak mampu menjadi agen transformasi fundamental bagi para pemeluknya. Sebaliknya, penghayatan praktik kehidupan agama yang ritualistik dan formalistik justru menjadikan agama tidak mampu mengembangkan kualitas moral, integritas diri, dan perilaku religius yang sejati dari para pemeluknya. ${ }^{15}$

\section{Gereja Partisipatif-Memasyarakat: Keluar dari Kungkungan Ritualistik}

Seluruh aktivitas gerejawi umat Paroki Kesatrian selama pandemi tampaknya lebih menekankan sisi perayaan iman dan ritual keagamaan saja. Keterlibatan dalam lingkungan masyarakat tidak begitu tinggi. Hal ini ditakutkan akan menjadi penyebab munculnya Gereja yang ritualitstik. Padahal Gereja yang dicetuskan oleh Gaudium et Spes sejatinya menawarkan Gereja yang keluar dari kungkungan ritualistik. Penulis berpendapat bahwa Gereja yang partisipatif dan memasyarakat adalah pertama-tama Gereja yang hadir sebagai sakramen dan dari dirinya muncullah kesejahteraan umum yang disokong oleh opsi bagi kaum miskin dan tersisih dalam semangat solidaritas. ${ }^{16}$

Apabila menyelisik kembali pandangan Konsili, Lumen Gentium menandaskan bahwa ciri khas dan tugas khusus kaum awam dalam kehidupan Gereja terletak pada tugas di tengah dunia dan masyarakat. Kehadiran awam dan partisipasinya dalam kehidupan gerejani bertujuan untuk menguduskan dunia, meresapi pelbagai bidang urusan duniawi dengan semangat Kristus. Mereka belajar dari semangat dan cara hidup Kristus, yakni mengolah seluruh dunia bagaikan ragi, garam, dan terang, sehingga Kerajaan Allah bisa hadir di tengah masyarakat. ${ }^{17}$ Intinya, berdasarkan panggilan khasnya kaum awam bertugas mencari Kerajaan Allah dengan mengusahakan hal-hal duniawi dan mengaturnya sesuai dengan kehendak Allah.

Idealisme ini sulit terjadi jika kehidupan kegerejaan umat Katolik hanya memberikan penekanan pada aspek ritual. Hal ini tidak itu mengatakan bahwa ritual gerejani tidak penting. Perutusan Gereja untuk menggarami dunia menemukan sumber kekuatan dan inspirasinya dari perayaan ritual, terutama ekaristi. Ritual gerejani menjadi daya dorong umat untuk keluar dari dirinya sendiri dan berjumpa dengan manusia di tengah pergumulan mereka yang konkret. Namun, Gereja juga mengecam perilaku ibadat yang munafik dan pandangan yang keliru tentang ritual kristiani, seolah-olah Allah tampil sebagai seorang raja

\footnotetext{
${ }^{14}$ Prasetyo dan Mahamboro, "BERKUBANG DALAM LUMPUR”, 87.

${ }^{15}$ Robertus Wijanarko, "Memahami Medan Pelayanan Gereja Indonesia Dewasa Ini (Tantangan Menghadirkan Gereja Gembira dan Berbelaskasih)," Seri Filsafat Teologi 25, no. 24 (2015): 273-88.

${ }^{16}$ Prior, Allah Mengugat, 113.

${ }^{17}$ Norbertus Jegalus, “TANGGUNG JAWAB AWAM DALAM PERUTUSAN DIAKONIA GEREJA," Lumen Veritatis: Jurnal Filsafat dan Teologi 10, no. 1 (1 Oktober 2019): 97-122, https://doi.org/10.30822/LUMENVERITATIS.V10I1.218.
} 
surgawi yang menuntut haknya dari manusia dalam bentuk korban besar dan rupa-rupa tindakan peribadatan. ${ }^{18}$ Sebenarnya, cara pandang ini tidak dikenal dalam teologi liturgi Gereja Katolik. Tindakan ritual atau liturgi pertama-tama adalah tindakan Allah yang menguduskan dan menyelamatkan manusia dan dunia. Korban syukur dan pujian kepada Allah merupakan tanggapan manusia atas tindakan penyelamatan Allah.

Tantangan Gereja partisipatoris adalah kecenderungan Gereja yang pastor-sentris. Kegiatan Gerejawi didominasi oleh pastor atau hanya oleh beberapa umat saja. Padahal karya-karya pastoral Gereja bukan hanya tugas pastor, tetapi juga tanggung jawab semua orang beriman. Umat juga memiliki kewajiban untuk mewartakan Injil. Dari kesaksian kisah Para Rasul kita tahu bahwa pewarta Injil bukan hanya kelompok 12 (para rasul) atau kelompok tujuh (pelayan meja), melainkan juga kaum beriman awam. ${ }^{19}$

Idealnya, karya-karya pastoral Gereja haruslah senantiasa aktual supaya dapat menyentuh segi-segi hidup jemaat yang konkret. Karya pastoral mesti kontekstual, artinya selalu terarah kepada kepentingan jemaat. Keberhasilan karya pastoral yang berciri kontekstual pun amat tergantung dari kemampuan memahami seluk beluk jemaat secara tepat, karena pada hakikatnya karya Pastoral itu menyuburkan hidup Gereja. ${ }^{20}$ Pelayanan pastoral Gereja harus terintegrasi. Hal ini memaksudkan bahwa Gereja tidak hanya mengurus liturgi. Pelayanan pastoral Gereja menyangkut lima bidang perutusan Gereja, yakni kerygma (pewartaan), diakonia (pelayanan), leiturgia (menguduskan), koinonia (persekutuan), dan martiria (kesaksian). Semuanya harus mendapat penekanan yang seimbang, serta mesti berjalan beriringan dan simultan.

Pandemi Covid-19 menyebabkan karya pastoral Gereja yang integral ini tidak dapat dipraktikkan sepenuhnya. Urusan Gerejawi mayoritas dipegang oleh orang tertentu saja termasuk para imam. Maka, sulitlah menghadirkan Gereja yang terlibat secara utuh dalam lima bidang pelayanannya. Di samping itu, para hierarkis Gereja perlu hadir dalam urusan sosial politik kemasyarakatan. Keterlibatan para hierarkis dalam urusan sosial-politik bukan dalam arti merebut kekuasaan politis, melainkan membawa suara moral Gereja dan menyuarakan pentingnya kebaikan bersama di tengah realitas politik yang pragmatis dan mencari keuntungan sendiri. Tanggung jawab dalam urusan sosial-politik terungkap lewat usaha menghimpun dan memberi pendampingan iman, ilmu, dan pembentukan karakter kristiani kepada awam supaya menjadi terang dan garam dunia melalui kegiatan sosial, politik dan ekonomi serta budaya yang ditekuni. ${ }^{21}$ Di sini letak peran serta atau keterlibatan para imam atau hierarkis dalam konsep Gereja yang partisipatif-memasyarakat. Pendampingan terhadap para awam itu dimulai dengan upaya membangun sebuah

\footnotetext{
18 Jegalus, 97-122.

${ }^{19}$ Didik Bagiyowinadi, "Mewartakan Injil dengan Gembira dan Berbelas Kasih Belajar dari Gereja Para Rasul," Seri Filsafat Teologi 25, no. 24 (2015): 169-89.

${ }^{20}$ St. S Gitowiratmo, Gagasan Dasar Pastoral Berbasi Data (Yogyakarta: Kanisius, 2017).

21 Norbertus Jegalus, "TANGGUNG JAWAB AWAM DALAM PERUTUSAN DIAKONIA GEREJA," Lumen Veritatis: Jurnal Filsafat dan Teologi 10, no. 1 (1 Oktober 2019): 118.
} 
communio bersama awam. Hal ini bertujuan untuk melakukan refleksi bersama secara berkala dan kontinu tentang kenyataan-kenyataan sosial-politik sehari-hari. Refleksi ini dipertajam dengan membaca dan merenungkan bersama Kitab Suci, khususnya refleksi atas pribadi Yesus sebagai penyelamat dan pembebas. Refleksi itu kemudian diikuti oleh tindakan bersama demi suatu perubahan sosial-politik yang lebih adil dan manusiawi. ${ }^{22}$

Wajah Gereja yang partisipatif dan memasyarakat dalam situasi pandemi Covid-19 akan tampak pada diri Gereja yang solider. Solidaritas Gereja selama pandemi dapat mengikuti contoh solidaritas Gereja Para Rasul. Paulus menasihati umatnya dengan bercucuran air mata dan memberikan teladan bekerja dengan tangan agar dengan demikian dapat membantu yang lemah. Wajah Gereja yang solider menampilkan identitas Gereja di tengah pandemi Covid-19.

\section{Kesimpulan}

Gereja partisipatif-memasyarakat" menghadirkan pandangan tantang wajah Gereja di tengah pandemi Covid-19, yakni Gereja yang keluar dari gambaran dan praktek ritualistik belaka. Gereja yang demikian menghadirkan dirinya dalam solidaritas terhadap sesama yang menderita dan terdampak Covid-19. Alasan yang mendasar bagi gambaran Gereja yang solider ditemukan dalam ungkapan Kitab Suci berikut ini: "Allah tetap setia kepada orang yang dihina, menjamin keadilan bagi orang yang tertindas. Tuhan memberi makan kepada orang yang lapar, membebaskan orang yang terbelenggu. Tuhan membuka mata orang buta, menegakkan orang yang bungkuk. Tuhan melindungi orang asing, memelihara para yatim piatu dan janda" (Mzm 146:7-9).

Situasi pandemi Covid-19 memang tidak menghilangkan iman umat Paroki Ratu Rosari Kesatrian Malang. Hanya saja, dampak situasi pandemi kelihatan dalam penurunan keterlibatan umat dalam kegiatan gerejani. Namun, ada fakta lain juga bahwa umat yang tidak pernah aktif dalam kegiatan kegerejaan justru menjadi lebih aktif selama masa pandemi. Memang, keterlibatan anggota Gereja tidak dapat terbatas pada keterlibatan internal saja. Keterlibatan gerejani harus terarah keluar dan menyentuh masyarakat sekitar. Inilah karakteristik dari Gereja yang partisipatif sekaligus memasyarakat. Keterlibatan Gereja yang dimaksud terungkap dalam identitas Gereja sebagai persekutuan, sebagai communion of community. Gereja yang partisipatoris adalah Gereja yang memberi kesaksian dan tampil sebagai agen transformasi. Gagasan-gagasan ini dapat diterapkan dalam situasi pandemi Covid-19, di mana Gereja dipanggil untuk membangun keterlibatan baik ad intra maupun ad extra.

\footnotetext{
22 Ola Rangan Wihelmus, Menebar Garam di atas Pelangi, ed. oleh Hipolitus K Kwuel dan Gabriel Sunyoto (Madiun: Wina Press, 2019).
} 


\section{Daftar Kepustakaan}

Bagiyowinadi, Didik. "Mewartakan Injil Dengan Gembira Dan Berbelas Kasih Belajar Dari Gereja Para Rasul.” Seri Filsafat Teologi 25, no. 24 (2015): 169-89.

Bevans, Stephen. Teologi dalam Perspektif Global. Maumere: Ledalero, 2010.

Dien, Novry. "Gereja Persekutuan Umat Allah.” Media (Jurnal Filsafat dan Teologi) 1, no. 1 (2020): 49-64.

Gitowiratmo, St. S. Gagasan Dasar Pastoral Berbasi Data. Yogyakarta: Kanisius, 2017.

Jegalus, Norbertus. "TANGGUNG JAWAB AWAM DALAM PERUTUSAN

DIAKONIA GEREJA.” Lumen Veritatis: Jurnal Filsafat dan Teologi 10, no. 1 (1 Oktober 2019): 97-122.

https://doi.org/10.30822/LUMENVERITATIS.V10I1.218.

Kirchberger, George. Allah Menggugat. Maumere: Ledalero, 2007.

Pandego, Higianes Indro. "GEREJA UMAT ALLAH SEBAGAI KOMUNIO

PARTISIPATIF Refleksi Yuridis-Pastoral atas KHK 1983, Kann.204-207.”

LOGOS 17, no. 2 (16 Juli 2020): 106-27.

Phillips, Peter. "Gaudium et Spes." Journal of Catholic Social Thought 13, no. 2 (2016): 245-59. https://doi.org/10.5840/jcathsoc20161327.

Prasetyo, Alis Windu, dan Dionius Bismoko Mahamboro. "BERKUBANG DALAM LUMPUR, BEKERJA BERSAMA ORANG MISKIN, Wajah Keterlibatan Sosial Gereja Ganjuran.” Jurnal Teologi (Journal of Theology) 2, no. 1 (2014): 83-91.

Prior, John Mansford. Allah Mengugat Allah Menyembuhkan. Disunting oleh Dkk Paul Budi Kleden. Maumerre: Ledalero, 2012.

"Surat Edaran Menteri Agama Nomor 23 Tahun 2020 Tentang Panduan Penyelenggaraan Kegiatan Ibadah Dan Perayaan Natal DI Masa Pandemi COVID-19 Kementrian Agama RI.” Diakses 2 September 2021. https://kemenag.go.id/archive/suratedaran-menteri-agama-nomor-23-tahun-2020-tentang-panduan-penyelenggaraankegiatan-ibadah-dan-perayaan-natal-di-masa-pandemi-covid-19.

Tan, Jonathan Yun-Ka. "A New Way of Being Church in Asia: The Federation of Asian Bishops' Conferences (FABC) at the Service of Life in Pluralistic Asia." Missiology: An International Review 33, no. 1 (Januari 2005): 72-94. https://doi.org/10.1177/009182960503300107.

Wihelmus, ola Rangan. Menebar Garam di atas Pelangi. Disunting oleh Hipolitus K Kwuel dan Gabriel Sunyoto. Madiun: Wina Press, 2019.

Wijanarko, Robertus. "Memahami Medan Pelayanan Gereja Indonesia Dewasa Ini (Tantangan Menghadirkan Gereja Gembira Dan Berbelaskasih).” Seri Filsafat Teologi 25, no. 24 (2015): 273-88. 